\title{
維持透析患者の細胞性免疫
}

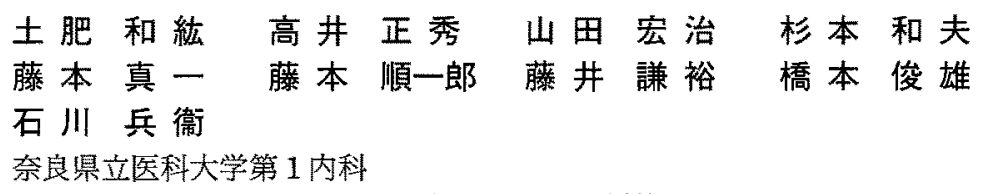

(昭和 62 年 6 月 29 日受付)

key words : ADCC 活性, AMLR, 維持透析患者, NK 活性, サプレッサーT細胞機能

〈要旨〉

維持透析 (HD) 患者では結核罹患率や発癌率が高いという事実から, 最近ではHD 患者における細胞性免疫異常が 注目されている. そこでわれわれは HD 患者の natural killer (NK) 活性, antibody-dependent cell-mediated cytotoxicity (ADCC) 活性, autologous mixed lymphocyte reaction (AMLR) および concanavalin A 誘導サブレッ サーT細胞 (Con A-Ts) 機能について検討し, 併せてモノクローナル抗体を用いてリンパ球サブセットを解析した. 対象は 30 例の HD 患者であり，健常成人 100 例を対照に選んだ. NK およびADCC 活性は標的細胞にそれ艺れ K562 細胞, ニワトリ赤血球を用いた ${ }^{51} \mathrm{Cr}$ 遊離法の測定によった。 AMLR の評価は non T 細胞に対する $\mathrm{T}, \mathrm{T} \gamma$ および $\mathrm{T}$ non $\gamma$ 細胞の反応性, Con A-Ts 機能は pokeweed mitogen で刺激された一定健常人リンバ球の增殖能に対する Ts 細胞の抑制効果によった. リンパ球サブセットの解析は OKT および Leu シリーズによるフローサイトメトリーに よった. HD 患者の NK 活性, ADCC 活性は光れぞれ $14.5 \pm 1.6 \%, 20.7 \pm 2.2 \%$ あり, 健常対照の $30.9 \pm 1.4 \%$, $34.8 \pm 2.2 \%$ に比して有意に低下していた. HD 患者の AMLR は T, T $y$, T non $\gamma$ のすべてが健常対照に比して有意に 低下していた。，一方，HD 患者の Con A-Ts 機能は健常対照と有意の差を示さなかった.リンパ球サブセットの解析 では健常対照に比して HD 患者の Leu 3a, OKM1, Leu 11 a, OKla1, HLA-DR 陽性細胞出現率が有意の増加を, Leu 2a 陽性細胞出現率が有意の減少を示した。 しかし HD 患者の OKT3，OKT4，OKT8，Leu 4 および Leu 7 陽性細胞出現率 は健常対照と明らかな差を示さなかった，つまり HD 患者についてはNK 活性, ADCC 活性およびAMLR が低下し ているので, 腫瘍免疫監視, ウイルス感染防御や自己認識などに機能異常が存在するものと考えられる.さらに OKM 1 , Leu 7 およびLeu 11a 陽性細胞出現率は減少していないので, NK 活性の低下は量的な異常ではなく質的な異常によ るものと思われる.

\section{Cellular immunity in patients undergoing maintenance hemodialysis}

Kazuhiro Dohi, M. D., Masahide Takai, M. D., Hiroharu Yamada, M. D., Kazuo Sugimoto, M. D., Shinichi Fujimoto, M. D., Junichiro Fujimoto, M. D., Yoshihiro Fujii, M. D., Toshio, Hashimoto, M. D., Hyoe Ishikawa, M. D.

The First Department of Internal Medicine, Nara University.

The effect of hemodialysis on cell-mediated immunity was investigated in 30 hemodialysis patients. Several parameters of cell-mediated immunity, such as natural killer (NK) activity, antibody-dependent cell-mediated cytotoxicity (ADCC), concanavalin A-induced suppressor Tcell function (Con A-Ts), autologous mixed lymphocyte reaction (AMLR) and analysis of lymphocyte subsets using monoclonal antibodies by fluorescence -activated cell sorter, were assessed in these patients.

The NK activities of NK cells and ADCC were significantly decreased in hemodialysis patients compared with normal subjects. Moreover, AMLR of whole T cells, T $\gamma$ cells and T non $\gamma$ cells were significantly decreased in hemodialysis patients compared with normal subjects. However, the Con A-Ts in hemodialysis patients was 土 肥 和 紘 奈良県立医科大学第 1 内科 T 634 㯖原市四条町 $840(07442-2-3051)$ normal.

Peripheral lymhocyte subsets were measured using 
monoclonal antibodies (OKT and Leu series). The percentage of Leu3a, OKM1, Leu11a, OKIa1 and HLA-DR positive cells were significantly higher in the hemodialysis patients, whereas the percentage of Leu2a positive cells was significantly decreased. In contrast, there was not such a big difference in the percentage of OKT3, OKT4, OKT8, Leu4 and Leu7 positive cells between the two groups.

We also studied the influence of blood transfusion on cellular immunity in hemodialysis patients. A marked decrease in AMLR between $T \gamma$ and non T cells was observed in blood transfused patients.

Concerning other cellular immunological functions, no abnormal findings were observed in blood transfused patients.

These results indicate that hemodialysis patients may have defects in immunological surveillance for neoplasma, defense against viral infections and the self-recognition mechanism.

\section{緒言}

従来から結核や癌の䍜患率が高い ${ }^{1,2)}$ とか, 臟器移植の 拒絶反応が弱い3)などの事実から維持透析 (HD) 患者に は細胞性免疫の低下が存在すると考元られてきた。機能 的には，末梢血リンパ球数あるいは分画，㩔延型皮膚反 応およびリンパ球幼若化反応などが検討されており, $\mathrm{HD}$ 患者においては特にT細胞機能低下が指摘されてい る4).今回われわれは, HD 患者の細胞性免疫をより詳細 に検討する目的で，キラー細胞機能を natural killer (NK) 活性および antibody-dependent cell-mediated cytotoxicity (ADCC) 活性, サプレッサーT細胞機能を 一定健常人リンパ球の増殖能に対する concanavalin A ( con A) 誘導サプレッサーT細胞の抑制効果, 自己認識 過程を各種 $\mathrm{T}$ 細胞サブセット（T, T $\gamma, \mathrm{T}$ non $\gamma$ )に扔け る autologous mixed lymphocyte reaction (AMLR) で 検討し，併せてモノクローナル抗体を用いたフローサイ トメトリーによりリンパ球サブセットを解析した。

\section{対象と方法}

\section{1. 対象}

対象は奈良県立医科大学附属病院第 1 内科㧍よびその 関連病院に通院中の維持透析患者 30 例で, 性別は男性 10 例, 女性 20 例, 年齢は 29-62 (平均 43.2) 歳であった。 な㧍, 対象の原疾患は全例が慢性系球体腎炎であり，対 象の HD 期間, へモグロビン值, 透析前 BUN 值扔よ び透析前クレアチニン值は表 1 に示すと抢りである. さらに，健常対照に健常成人 100 例を選んだ. 性別は

\begin{tabular}{|c|c|c|}
\hline 透析患者 & 30 例 & （男性10例，女性20例） \\
\hline 年齢 & 平均 43.2 歳 & (29-62 歳) \\
\hline 透析期間 & 平均 5.2 年 & （0.25-14.5 年） \\
\hline ヘモグロビン值 & 平均 $7.6 \pm 1.7 \mathrm{~g} / \mathrm{d} l$ & $(5.0-12.9 \mathrm{~g} / \mathrm{d} l)$ \\
\hline 血清総タンパク量 & 平均 $7.3 \pm 0.6 \mathrm{mg} / \mathrm{d} l$ & $(5.4-8.7 \mathrm{mg} / \mathrm{d} l)$ \\
\hline 透析前 BUN 值 & 平均 $60.4 \pm 10.3 \mathrm{mg} / \mathrm{d} l$ & $l l(43-84 \mathrm{mg} / \mathrm{d} l)$ \\
\hline 透析前クンアチニン值| & 平均 $10.1 \pm 2.2 \mathrm{mg} / \mathrm{d} l$ & $(6.5-16.3 \mathrm{mg} / \mathrm{d} l)$ \\
\hline
\end{tabular}

男性 58 例，女性 42 例で年齢は 18 歳から 59 歳（平均 27.1 歳) であった。

2. 方法

1) NK 活性

$\mathrm{NK}$ 活性は ${ }^{51} \mathrm{Cr}$ 遊出法により測定した。ヘパリン加 末梢血に $5 \%$ シリカ懸濁液 (日本抗体研究所製) を加え, $37^{\circ} \mathrm{C}, 60$ 分間静置して単球を除去した。ついで Ficoll -Hypaque (Pharmacia 製) 比重遠心法により末梢血り ンパ球 $(\mathrm{PBL})$ を分離した。培責液は RPMI 1640 （日水 製薬社製) に $10 \mathrm{vol} \%$ のウシ胎児血清 (FCS, Chimera Biomedics Corporation 製), $10 \mu \mathrm{g} / \mathrm{m} /$ の streptomycin (明治製菓社製)，10,000 U/d $l$ の penicillin $\mathrm{G}$ (明治製菓 社製）を添加して作成した。この培養液に PBL $2 \times$ $10^{6} / \mathrm{m} l$ の濃度となるように浮遊させ, これを effector 細 胞 (e) とした。 NK 細胞に対する標的細胞 (t) は慢性骨 䯣性白血病由来の培養株 K562 を使用した。 $5 \times 10^{6} / 0.2$ $\mathrm{m} l$ の $k \mathrm{Na}_{2}{ }^{51} \mathrm{CrO}_{4}$ (New England Nuclear 製) $1 \mathrm{~m} l$ $(100 \mu \mathrm{Ci})$ を加元， $5 \% \mathrm{CO}_{2}, 37^{\circ} \mathrm{C}$ 下で 60 分間培養し $\mathrm{t}$

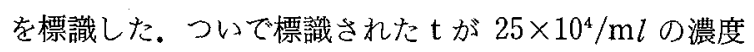
となるように培養液中に浮遊させた。U底マイクロプ レート (Corning 社製) に $1 \times 10^{4} / 0.04 \mathrm{~m} l$ の $\mathrm{t}$ と $2 \times 10^{5} /$ $0.1 \mathrm{~m} l$ の e を分注し $(\mathrm{e} / \mathrm{t}=20), 5 \% \mathrm{CO}_{2}, 37^{\circ} \mathrm{C}$ 中で 4 時間培養した。培養後, 各ウエルから上清を Titertek supernatant collection system で採取し, 遊離した ${ }^{51} \mathrm{Cr}$ 量をガンマシンチレーションカウンター (Packard, Model 5130) で測定した. NK 活性㹥次式で求めた。

$\mathrm{NK}$ 活性 $(\%)=\left(\right.$ 実験 ${ }^{51} \mathrm{Cr}$ 遊離一自然 ${ }^{51} \mathrm{Cr}$ 遊離 $) /($ 最 大 ${ }^{51} \mathrm{Cr}$ 遊離一自然 ${ }^{51} \mathrm{Cr}$ 遊離 $) \times 100$

なお, 最大遊離は $\mathrm{t}$ を $1 \mathrm{~N}$ の塩酸で処理した時の放射 活性で, 自然遊離は $\mathrm{t}$ のみを培養した時の放射活性で求 めた。

\section{2) ADCC 活性}

ADCC 活性は Perlmann ら ${ }^{5)}$ の方法に準じ, ${ }^{51} \mathrm{Cr}$ 遊出 法により測定した。単球除去後の PBL を前述の培養液 に浮遊させ, リンパ球数が $5 \times 10^{6} / \mathrm{m} l$ の濃度となるよう 
に調整し, effector 細胞（e）とした. $2 \times 10^{7} / 0.1 \mathrm{~m} l$ の ニワトリ赤血球 $(\mathrm{CRBC}) に 0.1 \mathrm{~m} l(100 \mu \mathrm{Ci})$ の $\mathrm{Na}_{2}{ }^{51}$ $\mathrm{CrO}_{4}$ 加えて ${ }^{51} \mathrm{Cr}$ 標識 $\mathrm{CRBC}$ を作製し, 標的細胞 $(\mathrm{t})$ とした。次に，非働化したウサギ抗 CRBC 抗体 IgG (日 本抗体研究所製) をPBSで 200 倍希釈後，その $1 \mathrm{~m} l$ を $\mathrm{t}$ に加えて $5 \% \mathrm{CO}_{2}, 37^{\circ} \mathrm{C}$ 下で 30 分間培養した．培養 後, $\mathrm{t}$ が $5 \times 10^{5} / \mathrm{m} l$ となるよう培養液中に浮遊させた。 そしてU底マイクロプレートに $5 \times 10^{4} / 100 \mu l$ の $\mathrm{t}$ と $25 \times 10^{4} / 50 \mu l$ のを各ウエルに分注した後（e / t = 5 ), $5 \% \mathrm{CO}_{2}, 37^{\circ} \mathrm{C}$ 下で 24 時間培養した。培養後, 各 ウエルから上清を Titertek supernatant collection system で採取し, 遊離 ${ }^{51} \mathrm{Cr}$ 量をガンマシンチレーション カウンターで測定した. ADCC 活性は次式により求め た。

$\mathrm{ADCC}$ 活性 $(\%)=\left(\right.$ 実験 ${ }^{51} \mathrm{Cr}$ 遊離一自然 ${ }^{51} \mathrm{Cr}$ 遊離 $) /$ (最大 ${ }^{51} \mathrm{Cr}$ 遊離一自然 ${ }^{51} \mathrm{Cr}$ 遊離) $\times 100$

なお，最大遊離は $\mathrm{t}$ の放射活性を直接測定することに より，自然遊離は CRBC を $10^{6}$ 個加えることにより測 定した。

\section{3) Con A-Ts 機能}

まずへパリン加末梢血を用い, Ficoll-Hypaque 液に よる比重遠心法で PBL を分離した。前述の培養液に $\mathrm{PBL}$ を $2 \times 10^{6} / \mathrm{m} l$ の濃度となるように調整して浮遊さ せ，さらにヒツジ赤血球 (SRBC, 日本抗体研究所製)を 加えてロゼットを形成させた後, Ficoll-Hypaque 比重 遠心法でロゼット形成細胞（T細胞）と非ロゼット形成 細胞 (non T 細胞) を分離した。ついで SRBC に $0.17 \mathrm{M}$ トリス緩衝液 $(\mathrm{pH}$ 7.2) を加える低張処理で $\mathrm{SRBC}$ を溶 血させ， T細胞を得た。このT細胞を $1 \times 10^{6} / \mathrm{m} l$ の濃度 となるように調整して培養液中に浮遊させた。その細 胞を平底マイクロプレートに $20 \mu \mathrm{g} / \mathrm{m} l$ の濃度となるよ うに調整した con A (Pharmacia 社製) $0.02 \mathrm{~m} l$ の存在 下抢よび非存在下に $0.2 \mathrm{~m} l$ ずつ分注し， $5 \% \mathrm{CO}_{2}, 37^{\circ} \mathrm{C}$ の条件下で 48 時間培養した。培養後, $0.1 \mathrm{M} の \alpha$-methyl -D-mannoside (Fluka 社製) を加えて con A を除去し, con A 誘導サプレッサーT細胞 (Con A-Ts) を得た。ま た con A 無添加の非誘導 T細胞を対照細胞とした。両者 とも $1 \times 10^{6} / \mathrm{m} l$ の濃度となるょう調整して培養液中に 浮遊させ，これらを刺激細胞とした，反応細胞は同一健 常人の PBL $\left(1 \times 10^{6} / \mathrm{m} l\right)$ を用いた。 反応細胞と刺激細 胞をそれぞれ $0.1 \mathrm{~m} l /$ ウルずつ混合し，培養液で 2.5 $\mu \mathrm{l} / \mathrm{m} l$ になるように調整した pokeweed mitogen (PWM, GIBCO 社製) を各ウエルに $20 \mu l$ ずつ添加し て $37^{\circ} \mathrm{C}, 5 \% \mathrm{CO}_{2}$ 中で混合培養した。また同時に, Con $\mathrm{A}-\mathrm{Ts}$ 朽よび対照細胞はいずれも単独に, PWMを加え て培養した。培養 96 時間後に, $0.25 \mu \mathrm{Ci}$ の ${ }^{3} \mathrm{H}$ -thymidine (Amersham 社製) を加えた。さらに 16 時 間培養後, cell harvester (Labo Mash 社製) でリンパ 球をガラスフィルターに吸着させ, ${ }^{3} \mathrm{H}$-thymidine $の$ 取 り込みを液体シンチレーションカウンター (LS 7500, Beckman 社製) で測定した. Suppression index (SI) を下記の計算式で求め, Con A-Ts 機能の評価に用いた。

$\mathrm{SI}=(1-\mathrm{Con} \mathrm{A}-\mathrm{Ts} の \triangle \mathrm{cpm} /$ 対照細胞の $\triangle \mathrm{cpm}) \times 100$

Con A-Ts $0 \triangle \mathrm{cpm}=($ Con A-Ts と健常人 PBL 混合 培責時の取り込み $)-(\operatorname{Con} A-T s$ 単独培養時の取り込 み)

刘照細胞の $\triangle \mathrm{cpm}=($ 対照細胞と健常人 $\mathrm{PBL}$ 混合培 養時の取り込み) - (対照細胞単独培養時の取り込み)

\section{4) AMLR}

リンパ球の分離：ヘパリン加末梢血から前述した方法 で単球を除去した PBLを分離した。分離後, E-rosette 法でT細胞, non T細胞を得た。

$\mathrm{T} \gamma$ および $\mathrm{T}$ non $\gamma$ 細胞の分離: 抗ウシ赤血球イエ ウサギ IgG 抗体（日本抗体研究所製）で感作したウシ赤 血球を，その濃度が $5 \%$ となるように前述の培責液中に 浮遊させた。つぎに分離したT細胞が $5 \times 10^{6} / \mathrm{m} l$ となる ように培養液中に調整して浮遊させた後, 等量のウサギ IgG 感作ウシ赤血球を加えて IgG receptor を持つ T細 胞 ( $\mathrm{T} \gamma$ 細胞) と EA-rosette を形成させた. Rosette 形 成後, Ficoll-Hypaque 法により $\mathrm{T} \gamma$ 細胞と $\mathrm{T}$ non $\gamma$ 細 胞とに分離した。

リンパ球混合培養： T細胞， $\mathrm{T} \gamma$ 細胞および $\mathrm{T}$ non $\gamma$ 細胞は培養液中の細胞数がいずれも $1 \times 10^{6} / \mathrm{m} l$ となる ように調整して $37^{\circ} \mathrm{C}, 5 \% \mathrm{CO}_{2}$ の条件下で 24 時間静置 し，これを反応細胞に用いた。つぎに mitomycin C (MMC, 協和発酵社製) をその濃度が $2.5 \mu \mathrm{g} / \mathrm{m} l$ となる ように non T細胞浮遊液に加え, $37^{\circ} \mathrm{C}, 5 \% \mathrm{CO}_{2}$ の条 件下で 30 分間培養し, 刺激細胞とした。 $\mathrm{T}$ 細胞, $\mathrm{T} \gamma$ 細 胞, T non $\gamma$ 細胞抢よびnon $\mathrm{T}$ 細胞を, $\mathrm{T}$ と non $\mathrm{T}, \mathrm{T} \gamma$ と non T, T non $\gamma$ と non T の組み合わせでそれぞれ $100 \mu l$ ずつの細胞を混合して， $37^{\circ} \mathrm{C} ， 5 \% \mathrm{CO}_{2}$ 下で 144 時間培養した (AMLR). 同時に反応細胞である T細胞, $\mathrm{T} \gamma$ 細胞および T non $\gamma$ 細胞をそれぞれ $100 \mu l$ ずつ単 独に 144 時間培養した (反応 $\mathrm{T}$ 細胞単独). 培養終了 24 時 間前に $0.25 \mu \mathrm{Ci}$ の ${ }^{3} \mathrm{H}$-thymidine を各培養系に加え, ${ }^{3}$ $\mathrm{H}$-thymidine の取り込みを液体シンチレーションカウ ンターで測定した。

AMLR は次式によって求めた $\triangle \mathrm{cpm}$ で評価した。 $\triangle \mathrm{cpm}=(\mathrm{AMLR}$ の取り込み $)-($ 反応 $\mathrm{T}$ 細胞単独の取 り込み)

5 ）モノクローナル抗体による末梢血リンパ球サブ セットの解析 
表 $2 \mathrm{HD}$ 患者の NK 活性, ADCC 活性, Con A-Ts 機能

\begin{tabular}{c|ccc}
\hline 群別 & NK 活性 (\%) & ADCC 活性 (\%) & Con A-Ts 機能(\%) \\
\hline 対照群 & $30.9 \pm 1.4$ ) & $34.8 \pm 2.2$ ) & $44.8 \pm 4.1$ \\
HD 群 & $14.5 \pm 1.6 \%$ & $20.7 \pm 2.2 \%$ & $42.3 \pm 4.2$ \\
\hline
\end{tabular}

**; $;<0.01$
表 3 HD 患者の AMLR

\begin{tabular}{|c|c|c|c|}
\hline 群別 & T-non $\mathrm{T}(\mathrm{cpm})$ & $\mathrm{T} \gamma$-non $\mathrm{T}(\mathrm{cpm})$ & $\mathrm{T}$ non $\gamma$-non T (cpm) \\
\hline 対照 & $20,819 \pm 2,373$ & $13,769 \pm 800$ & $21,957 \pm 2,643 \quad$ ) \\
\hline HD 群 & $5,295 \pm 706$ & $1,730 \pm 354$ & $7,927 \pm 1,389 \stackrel{* *}{*}$ \\
\hline
\end{tabular}

$* * ; \mathrm{p}<0.01$

表 4 HD 患者のリンバ球サブセット解析

OKT シリーズによるリンバ球サブセット解析

\begin{tabular}{|c|c|c|c|c|c|c|}
\hline 群別 & OKT3 & OKT4 & OKT8 & OKIaI & OKMI & OKT $4 / 8$ \\
\hline 対血群 & $68.3 \pm 1.2$ & $41.2 \pm 0.8$ & $26.5 \pm 0.7$ & $14.7 \pm 0.8\}$ & $13.0 \pm 0.9$ ? & $1.63 \pm 0.45$ \\
\hline HD 群 & $65.7 \pm 2.0$ & $44.1 \pm 1.9$ & $26.9 \pm 1.6$ & $23.0 \pm 2.0 \mathrm{j}^{* *}$ & $24.8 \pm 1.5{ }^{* *}$ & $1.89 \pm 0.17$ \\
\hline
\end{tabular}

Leu シリーズによるリンパ球サブセット解析

\begin{tabular}{|c|c|c|c|c|c|c|c|}
\hline 群別 & Leu2a & Leu3a & Leu4 & Leu7 & Leulla & HLA-DR & Leu $3 a / 2 a$ \\
\hline 対照群 & $27.8 \pm 0.7$ & $37.7 \pm 0.8\}_{* *}^{\prime}$ & $68.6 \pm 0.8$ & $20.7 \pm 0.9$ & $16.9 \pm 1.1 l_{* *}$ & $20.7 \pm 0.5$ ? & $1.5 \pm 0.6 ?$ \\
\hline HD 群 & $25.1 \pm 1.7$ & $43.8 \pm 1.7 \stackrel{\text { j* }}{ }$ & $67.3 \pm 1.9$ & $18.0 \pm 1.7$ & $23.7 \pm 2.0 \stackrel{\text { ** }}{ }$ & $35.9 \pm 2.6 \mathrm{~J}^{* *}$ & $2.1 \pm 0.2 \stackrel{*}{*}$ \\
\hline
\end{tabular}

$*: \mathrm{p}<0.05, * * ; \mathrm{p}<0.01$

末梢血リンバ球サブセット分析は OKT シリーズ・モ ノクローナル抗体 (Ortho Diagnostic Systems Inc. 製) および Leu シリーズ・モノクローナル抗体 (Becton Dickinson Monoclonal Center Inc. 製) を用いたフロー サイトメトリーによった。ヘパリン加末梢血 $100 \mu l$ を $100 \mu l$ の PBS で希釉後, モノクローナル抗体 $10 \mu l$ を 加之, $4{ }^{\circ} \mathrm{C}, 30$ 分間静置した. 静置後, lysing reagent $\left(0.8 \% \mathrm{NH}_{4} \mathrm{Cl}, 0.5 \mathrm{mM}\right.$ EDTA, $\left.0.1 \% \mathrm{KHCO}_{3}\right) 2 \mathrm{~m} l$ を 加兑て赤血球を溶血させ， $4{ }^{\circ} \mathrm{C}$ 条件下で遠沈後，細胞 を採取した。採取した細胞をPBS $1 \mathrm{~m} l$ に再浮遊させ， スペクトラムIII (Ortho-mune) で解析した。

6) 細胞性免疫に対する輸血の影響をみるため以下の ように対象を分けて検討した。1度でも輸血を受けたこ とのある症例を輸血（十）群とし，1度も輸血を受けて いない症例を輸血（一）群とした，この両群の細胞性免 疫を比較して輸血の細胞性免疫に及ぼす影響を検討し t.

\section{成績}

\section{NK 活性}

HD 患者群の NK 活性は $14.5 \pm 1.6 \%$ あり, 健常対 照群の $30.9 \pm 1.4 \%$ に比し， $\mathrm{p}<0.01$ で有意に低下して いた（表 2).

2. ADCC 活性

HD 患者群の ADCC 活性は $20.7 \pm 2.2 \%$ であり, 健常 対照群の $34.8 \pm 2.2 \%$ に比し， $\mathrm{p}<0.01$ で有意に低下し ていた（表 2).

\section{Con A-Ts 機能}

HD 患者群の Con A-Ts 機能は 42.3土4.2\%であり，
健常対照群の $44.8 \pm 4.1 \%$ に比して有意の差を示さな かった (表 2).

\section{AMLR}

HD 患者群に招ける $\mathrm{T}, \mathrm{T} \gamma$ 抢よび $\mathrm{T}$ non $\gamma$ 細胞の AMLR はそれぞれ $5,295 \pm 706 \mathrm{cpm}, 1,730 \pm 354 \mathrm{cpm}, 7$ ， $927 \pm 1,389 \mathrm{cpm}$ であり, 健常対照群の $20,819 \pm 2,373$ cpm, $13,769 \pm 800 \mathrm{cpm}, 21,957 \pm 2,643 \mathrm{cpm}$ に比していず れも $\mathrm{p}<0.01$ で有意に低下していた（表 3 ).

5.リンバ球サブセットの解析

OKT シリーズ：HD 患者群の OKIa1 陽性細胞出現率 は $23.0 \pm 2.0 \%$ であり，健常対照群の $14.7 \pm 0.8 \%$ に比し て有意に増加していた $(\mathrm{p}<0.01)$ ，同椂に OKM1につ いても HD 患者群は $24.8 \pm 1.5 \%$ あり，健常対照群の $13.0 \pm 0.9 \%$ に比して有意の增加を示した $(\mathrm{p}<0.01)$. 一方, OKT3，OKT4，OKT8 の陽性細胞出現率および OKT $4 / 8$ 此は HD 患者群と健常対照群との間に明らか な差を示さなかつた（表 4).

Leu シリーズ：HD 患者群におけるLeu 2a 陽性細胞 出現率は $25.1 \pm 1.7 \%$ ありり，健常対照群の $27.8 \pm 0.7 \%$ に比して有意に低下していた $(\mathrm{p}<0.05)$ ，一力，Leu 3a 陽性䋹胞出現率については HD 患者群が $43.8 \pm 1.7 \%$ で あり，健常対照群の $37.7 \pm 0.8 \%$ に比して有意の增加を 示した $(\mathrm{p}<0.01)$ 。また HD 患者群の Leu $3 \mathrm{a} / 2 \mathrm{a}$ 比は $2.1 \pm 0.2$ ですり, 健常対照群の $1.5 \pm 0.6$ 亿比して有意 の增加を示した $(\mathrm{p}<0.01)$. Leu 4 战よび Leu 7 陽性 細胞の出現率は雨群間に明らかな差を示さなかった。 HD 㭧者群の Leu 11a 陽性細胞出現率は $23.7 \pm 2.0 \%$ て あり，健常対照群の $16.9 \pm 1.1 \%$ に比して有意に増加し 
表 5 輸血の影響

\begin{tabular}{|c|c|c|c|c|c|c|c|c|}
\hline 輸血歴 & NK活性 & ADCC活性 & Con A-Ts & $\operatorname{AMLR}(\mathrm{T})$ & \multicolumn{2}{|c|}{$\operatorname{AMLR}(\mathrm{T} \gamma)$} & \multicolumn{2}{|c|}{ AMLR(T non $\gamma$ ) } \\
\hline 輸血十 & $13.6 \pm 8.8 \%$ & $18.8 \pm 8.9 \%$ & $50 \pm 14 \%$ & $3,299 \pm 762 \mathrm{cpm})$ & \multicolumn{2}{|c|}{$983 \pm 142 \mathrm{cpm})$} & \multicolumn{2}{|c|}{$5,230 \pm 2,049 \mathrm{cpm}$} \\
\hline 輸血一 & $15.0 \pm 8.0$ & $22.0 \pm 13.3$ & $37 \pm 25$ & $6,627 \pm 913$ & $2,227 \pm 542$ & & \multicolumn{2}{|c|}{$9,726 \pm 1,694$} \\
\hline 輸血歴 & OKT3 & OKT4 & OKT8 & OKIa1 & OKM1 & \multicolumn{2}{|c|}{ OKT4/8 } & \\
\hline 輸血十 & $65.8 \pm 11.6$ & $44.2 \pm 11.3$ & $27.1 \pm 8.9$ & $22.2 \pm 10.8$ & $24.4 \pm 7.8$ & \multirow{2}{*}{\multicolumn{2}{|c|}{$\begin{array}{l}1.95 \pm 0.34 \\
1.84 \pm 0.18\end{array}$}} & \\
\hline 輸血 - & $65.6 \pm 9.7$ & $44.1 \pm 9.0$ & $26.8 \pm 8.8$ & $23.6 \pm 10.8$ & $25.0 \pm 8.4$ & & & \\
\hline 輸血歴 & Leu2a & Leu3a & Leu4 & Leu7 & Leu1la & \multicolumn{2}{|c|}{ HLA-DR } & Leu3a/2a \\
\hline 輸血 十 & $24.2 \pm 9.1$ & $44.4 \pm 10.4$ & $68.5 \pm 10.5$ & $15.5 \pm 5.7$ & $21.1 \pm 6.7$ & \multicolumn{2}{|c|}{$35.6 \pm 12.7$} & $2.23 \pm 0.43$ \\
\hline 輸血一 & $25.6 \pm 9.3$ & $43.4 \pm 7.9$ & $66.5 \pm 9.9$ & $19.6 \pm 10.8$ & $25.4 \pm 12.7$ & \multicolumn{2}{|c|}{$36.2 \pm 14.9$} & $1.93 \pm 0.19$ \\
\hline
\end{tabular}

$* ; \mathrm{p}<0.05, * * ; \mathrm{p}<0.01$

ていた ( $\mathrm{p}<0.01)$ 。また, HD 患者群の HLA-DR 陽 性細胞出現率は $35.9 \pm 2.6 \%$ でり, 健常対照群の $20.7 \pm 0.5 \%$ に比して有意の増加 $(\mathrm{p}<0.01)$ を示した（表 $4)$.

\section{6. 細胞性免疫に対する輸血の影響}

つぎに HD 患者の細胞性免疫に対する輸血の影響を 検討した。表 5 に示したように, NK 活性, ADCC 活性, Con A-Ts 機能扔よびモノクローナル抗体を用いたリン パ球サブセット分析に対する輸血の影響については, 輸 血歴の有無による明らかな相違が認められなかった。し かし AMLR については輸血 (+) 群のT細胞および T $\gamma$ 細胞の AMLR がそれぞれ $3,299 \pm 762 \mathrm{cpm}, 983 \pm 142$ $\mathrm{cpm}$ であり, 輸血 (一) 群の $6,627 \pm 913 \mathrm{cpm}, 2,227 \pm 542$ $\mathrm{cpm}$ に比して有意の低下を示した $(\mathrm{T} ; \mathrm{p}<0.01, \mathrm{~T} \gamma$; $\mathrm{p}<0.05)$. 一方, T non $\gamma$ 細胞の AMLR は輸血（十）群 と輸血（一）群の間に有意の差がみられなかった。

\section{考察}

\section{NK 活性}

$\mathrm{NK}$ 細胞は特異的獲得免疫が作動する以前に発動する 初期防御の一員であり, 生体の自然抵抗性, とくに癌の 発生増殖に対し抵抗性を示すものとされている.HD 患 者における NK 活性の低下についてはすでに Badger ${ }^{6}$ によって報告されているが，今回の成績もそれを裏づけ たといえる. 発癌の免疫監視機構上重要な働きを持つ $\mathrm{NK}$ 細胞の機能低下は HD 患者における悪性腫黇多発

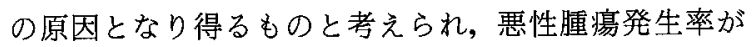
$\mathrm{HD}$ 患者で高いという報告が比較的多い2).

\section{2. $\mathrm{ADCC}$ 活性}

無感作マウスのリンパ球系細胞中に抗腫瘍抗体と協同 して腫湯細胞を傷害する細胞の存在が報告されており, この現象は antibody-dependent cell-mediated cytotoxicity (ADCC) と呼ばれる.そして抗体と協力し て前述の効果を示す細胞群が killer cell と命名されてい
る. $\mathrm{ADCC}$ 活性測定では標的細胞に有核培養細胞あるい は赤血球などが用いられるが，破壞作用機序は標的細胞 の相違により異なるとされている77。つまり HD 患者に おける ADCC 活性も使用する標的細胞によって成績が 異なることは容易に想像されるところである．今回の検 討ではニワトリ赤血球を標的細胞に用いたが，HD患者 の ADCC 活性は健常対照に比して有意に低下していた。 In vivo における $\mathrm{ADCC}$ の役割についてその全容が解明 されているわけではないが，腫場細胞やウイルス感染細 胞に対する傷害作用は確かなようである ${ }^{8)}$.したがって， 今回の検討で判明した HD 患者の ADCC 活性低下は, $\mathrm{HD}$ 患者では発癌率が高いという事実 ${ }^{2)} \mathrm{HB}$ 肝炎ウイ ルスキャリアの頻度が高いという事実" ${ }^{9}$ と関連している ものと思われる。また, ADCC 活性の六進は腎移植拒絶 反応を増強する因子となりうるとされており 応の低下は移植腎生着率の改善をもたらすかもしれな い. 実際に HD 患者では移植腎生着率が高いという報告 もみられる ${ }^{3)}$.

\section{Con A-Ts 機能}

サプレッサーT細胞は免疫応答の場において兔疫担当 細胞の過剩な反応を抑制し，免疫反応が適度なものとな るよう調整している、サプレッサーT細胞機能が低下す ると，免疫応答は過剩になるので自己免疫疾患の発現を 容易にする，逆にサプレッサーT細胞機能が充進したな らば免疫不全状態を招くことになるＨD患者において はサプレッサー細胞機能が元進しているとする報告が多 い.しかも mitogen などに対するリンパ球反応の低下は サプレッサー細胞機能の克進によるものとされてい る ${ }^{10)}$. しかし今回の検討では HD 患者の Con A-Ts 機 能は健常対照に比して明らかな差を示さなかった。この 成績は，サプレッサーT細胞機能穴進が必ずしも HD 患 者における細胞性免疫異常の主要な原因にはならないこ とを示したといえる。 


\section{AMLR}

AMLR とは自己 T細胞が自己 non T細胞膜上に存在 する HLA-DR 抗原 (Ia 抗原) を認識して, 自己 T 細胞 が分裂, 増殖することを示す，HD 患者では, 同種異系 リンパ球間の反応である mixed lymphocyte reaction の低下を述べた報告 ${ }^{11}$ は多いが, AMLRについての報告 はいまだ少ない。最近, 腎不全患者の AMLR は低下し ているという成績 ${ }^{22}$ が報告された。今回の検討でも，HD 患者の AMLR は低下していた. AMLR の意義は自己 認識過程を表わすことにあると考えられている ${ }^{13)}$.した がって AMLR の低下は自己認識過程の障害を示唆する ものであり，全身性エリテマトーデスやシェーグレン症 候群などの自己免疫疾患では AMLR が低下するという 報告 ${ }^{14)}$ を多くみることでも裏づけられている。つまり $\mathrm{HD}$ 患者では自己認識能力が低下しているのであり, 自 己抗体陽性例の頻度は高いという成績 ${ }^{15)}$ と関連があるの かもしれない.さらにインターロイキン 2 などのリンホ カインが AMLR で産生されるので ${ }^{13)}$, AMLR の低下は リンホカイン産生の低下につながり，間接的に NK 細胞 活性や lymphokine activated killer 細胞誘導の低下を もたらすと考えられる。したがって，AMLR の低下は究 極的に killer 細胞の抗腫瘍作用の障害を招くことにな る. Tのみならず $\mathrm{T} \gamma$ や T non $\gamma$ 細胞に対する AMLR のすべてが低下した今回の成䋶は，HD 患者においては 一部の T細胞分画のみが傷害されたためではなく，反応 細胞である T細胞全体かあるいは刺激細胞である non T細胞に対する抑制因子が存在するものと考えられる. しかも後述するように，モノクローナル抗体によるT細 胞分画の分析では, AMLR の主な反応細胞群とされてい る OKT4 および Leu3a の陽性細胞出現率が減少してい ないので, HD 患者に扔ける AMLR の低下はT細胞分 画の減少によるものでないことを示唆する.

5.モノクローナル抗体による末梢血リンパ球サブ セットの解析

T細胞分析：Raska ${ }^{16}$ の報告によると OKT3, OKT4 および OKT8 陽性細胞の出現率は，尿毒症および HD 患者の両者で健常対照に比して明らかな差を示さなかっ たという．また，OKT4/8 比が 1 以下を示す症例の出現 頻度については，HD患者は 50 例中 8 例 ( $16 \%)$ であり， 健常対照の 133 例中 6 例 (4.5\%) に比して高かったとい $3^{16)}$. 椿ら ${ }^{17)}$ の報告では， HD 患者の $\mathrm{OKT} 3$ おょび OKT4 の陽性細胞出現率は健常対照に比して有意の差 を示さなかったが, OKT8 陽性細胞出現率が有意に増加 していた。また野田 ${ }^{18)}$ は，HD患者の OKT3 陽性細胞出 現率は健常対照に比して増加を示したが, OKT4/8 比は 有意の変化を示さなかったという。一方，われわれの成
績では, OKT3, OKT4 おうよび OKT8 陽性細胞出現率が 健常対照と HD 患者の間に明らかな相違を示さなかっ た.つまり, OKT シリーズによるT細胞サブセット分析 は報告者によってすべて異なった結果を示しているとい えよう。この原因は対象の年齢，HD 期間あるいは輸血 歴などの背景因子が報告によって異なることによるのか もしれない。

HD 患者の Leu シリーズによる検討については坂 ロ ${ }^{19}$ はわれわれと同様に HD 患者群では Leu2a 陽性細 胞出現率の低下, Leu3a 陽性細胞出現率の増加, Leu4 陽 性細胞出現率は有意の変動なしという成績を示してい る.さらに Leu3a/2a 比は HD 期間が 4 から 8 年の症例 では上昇傾向を示したが，8年以上の症例では逆に低下

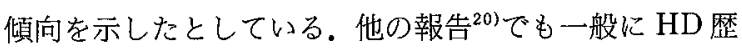
の長期化に伴い, Leu3a/2a 比が低下している。われわれ の検討では Leu3a/2a 比が上昇していたが，その原因は 対象とした HD 患者の HD 期間が平均 5.2 年であり, 長期透析例が少なかったことによると考えられる。

$\mathrm{NK}$ 細胞分析：NK 細胞の大部分は密度勾配遠心法の large granular lymphocyte (LGL) 分画内に入る。また LGL の大半が OKM1 抗体および Leu7 抗体と反応する とされ，この Leu7 陽性細胞の中でも Leu11a 陽性細胞 群は Leu11a 陰性細胞群より強い NK 活性を示すとい $う^{211}$. 今回の検討では HD 患者の OKM1, Leu7, Leu11a 陽性細胞出現率が低下していないので, HD 患者におけ る NK 活性低下は量的なものでなく質的なものと考え られる。

HLA-DR (Ia) 抗原陽性細胞の分析 : HLA-DR (Ia) 抗原は $\mathrm{B}$ リンパ球, 単球, 一部の null cell および活性化 された T細胞の細胞膜上に存在し, OKIa1 抗体や HLA -DR 抗体で認識される.今回の検討で認められた HD 患 者における OKIa1 抗体抢よび HLA-DR 抗体陽性細胞 率の増加は上記のうちのいかなる細胞群の増加によるも のか定かでない.

6. 細胞性免疫に対する輸血の影響

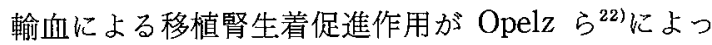
て確認されて以来，この点に関する検討が多くなされて おり, 今日では輸血のもつ移植腎生着促進作用は疑いの ないものとされている ${ }^{23)}$. そして生着促進の機序には細 胞性免疫の低下が関与するものとされ，輸血による MLR の低下が報告されている24)ＨD 患者においては 貧血に対して輸血が頻回に行なわれることから， HD 患 者の細胞性免疫については輸血の影響を無視できない. 今回の検討に扔ける $\mathrm{HD}$ 患者の $\mathrm{NK}$ 活性, $\mathrm{ADCC}$ 活性, Con A-Ts 機能拉よびリンパ球サブセット分析は輸血歴 の有無によって違いは認められなかった.しかし AMLR 
については，輸血歴を有する HD 患者における $\mathrm{T} と \mathrm{~T} \gamma$ 細胞の反応性が輸血歴のない患者に比して低下してい た，以上まとめてみると，輸血による細胞性免疫の障害 は主に自己認識過程にあると考えられる。また，輸血が 自己認識過程を混乱させて移植腎生着率を上昇させるも のと推測される。

\section{結論}

維持透析患者 30 例における細胞性免疫を検討し, 以下 の結果を得た。

1. 維持透析患者における NK 活性, ADCC 活性お よび T, T $\gamma$, T non $\gamma$ 細胞の AMLR は健常対照群に比 して有意に低下していた。

2.しかし維持透析患者の concanavalin A 誘導サプ レッサーT細胞機能（Con A-Ts 機能）は健常対照群に 比して明らかな差を示さなかった。

3. 維持透析患者の Leu3a, OKM1, Leu1la, OKIa1 お よび HLA-DR 陽性細胞率は健常対照群に比して有意の 増加を, Leu2a 陽性細胞率は有意の減少を示した。

4. 維持透析患者を輸血歴から輸血の既往のない輸血 (一) 群と過去に輸血の既往を有する輸血 $(+)$ 群に分け て検討した. NK 活性, ADCC 活性, Con A-Ts 機能㧈 よびリンパ球サブセット解析はいずれも輸血歴の有無に よって相違を示さなかった，しかし輸血（+）群におけ る $\mathrm{T}$ おひひ $\mathrm{T} \gamma$ 細胞の AMLR は輸血（一）群に比して 有意の低下を示した。

本論文の要旨は第 30 回人工透析研究会総会（昭和 60 年 7 月, 東京) 㧍よび第 28 回日本腎臟学会総会 (昭和 60 年 10 月, 東京）で発表した。

\section{文献}

1）稲本 元：尿毒症における免疫不全と結核症，透析 会誌, $12: 21-36,1979$

2) Sutherland GA, Glass J and Gabriel R : Increased incidence of malignancy in chronic renal failure. Nephron, $18: 182-184,1977$

3) Hume DM, Merrill JP, Miller BF and Thorn GW : Experiences with renal homotransplantation in the human : Report of nine cases. $\mathrm{J}$ Clin Invest, $34: 327-382,1955$

4) Kurz $P$, Köhler $H$, Meuer $S$, Hütteroth $T$ and Meyer zum Büschenfelde $\mathrm{KH}$ : Impaired cellular immune responses in chronic renal failure : Evidence for a T cell defect. Kidney Int, 29: 1209
$-1214,1986$

5) Perlmann $\mathrm{P}$ and Perlmann $\mathrm{H}$ : Contactual lysis of antibody-coated chicken erythrocytes by purified lymphocytes. Cell Immunol, 1 : 300-315, 1970

6) Badger AM, Bernard DB, Idelson BA and Cooperband, SR: Depressed spontaneous cellular cytotoxicity associated with normal or enhanced antibody-dependent cellular cytotoxicity in patients on chronic haemodialysis. Clin exp Immunol, $45: 568-575,1981$

7) 太田善介, 西谷晧次: 透析患者に抢ける NK, $\mathrm{ADCC}$, 好中球機能, インターフェロン産生能. 臨床 透析, 2:1983-1986, 1986

8）小室勝利：K細胞. 日本臨床, 42 (春季臨時増刊号)： 113-121, 1984

9) Rashid A, Senger D, McLeish W, Sutherland M, Harris J and Couture R : The effect of host immunity on hepatitis $\mathrm{B}$ antigen ( $\mathrm{HB} \mathrm{Ag}$ ) infection in hemodialysis patients. Trans Amer Soc Artif Int Organs, 21 : 483-487, 1975

10) Raskova J and Morrison AB : A decrease in cell -mediated immunity in uremia associated with an increase in activity of suppressor cells. Am J Pathol $84: 1-10,1976$

11) Kasakura $S$ and Lowenstein $L$ : The effect of uremic blood on mixed leukocyte reactions and on cultures of leukocytes with phytohemagglutinin. Transplantation, $5: 283-289,1967$

12) Frymoyer PA and Davey FR: Defective autologous mixed lymphocyte reactions in patients with renal insufficiency-evidence for cellular and serum factors. Clin Immunol Immunopathol, $34: 189-196,1985$

13）石田康生：II. 免疫応答の機構 2 . 自己 MLR一そ の意義と問題点一. 代謝, 20 (臨時増刊号)： 1413-1422, 1983

14）高井正秀, 土肥和紘, 藤井謙裕, 山田宏治, 金内雅 夫, 花谷正和, 野中秀郎, 石川兵衞: 自己免疫疾患 における $\mathrm{T}$ 細胞機能：concanavalin A 誘導抑制 $\mathrm{T}$ 細胞機能と autologous mixed lymphocyte reaction. 日臨免誌, 7:60-67, 1984

15) Casciani CU, Simone $C$, Bonini S, Gallucci $M T$, Matteucci G, Valesini G, Meli D. and Masala C : Immunological aspects of chronic uremia. Kidney Int, 13 (Suppl.) : 49-54, 1978

16) Raska K, Raskova J, Shea SM, Frankel RM, 
Wood RH, Lifter J, Ghobrial I, Eisinger RP and Homer $\mathrm{L}: \mathrm{T}$ cell subsets and celluar immunity in end-stage renal disease. Am J Med, $75: 734-740$, 1983

17）椿 和央, 前田裕弘, 数田康仁, 今田聡雄, 入交清 博, 堀内 篤: 長期透析患者のT細胞機能. 日腎誌, $26: 389-397,1984$

18）野田春夫：慢性血液透析患者の細胞性免疫能に関す る研究. 透析会誌, $18: 537-548,1985$

19）坂口泰弘：慢性血液透析患者における細胞性免疫に 関する研究：第二報モノクローナル抗体と FACS (fluorescence activated cell sorter)による 末梢 Tリンパ球サブセットの解析. 奈医誌, 35 ： 369-378, 1984

20) Hamaguchi $N$, Kobayashi M, Hirabayashi A, Shigemoto K, Usui K, Hayashi K, Yorioka N and Yamakido $\mathrm{M}$ : T lymphocyte subpopulations in patients undergoing chronic hemodialysis. Jap J
Nephrol, 26 : 1205-1212, 1984

21）安保 徹：免疫応答の機構 3 . NK 細胞のマー カーーその多様性の理由一.代謝, 20 (臨時増刊号)： 1423-1430, 1983

22) Opelz G, Senger DPS, Mickey MR and Terasaki PI : Effect of blood transfusions on subsequent kidney transplants. Transplant Proc, 5 : 253-259, 1973

23) Opelz G and Terasaki PI : International Histocompatibility Workshop Study on Renal Transplantation. In "Histocompatibility testing 1980" UCLA Tissue Typing Laboratory, Los Angeles, 592-624, 1980

24) Klatzmann D, Gluckman JC, Foucault C, Duboust A, Bensussan A, Assogba J and Berthelot JM : Modification of mixed lymphocyte reactivity after blood transfusions (BT) in man. Transplant Proc, 15 : 1016-1018, 1983 